\title{
Hubungan Pengetahuan Keluarga dengan Perilaku Pencegahan Penularan Tuberculosis Paru di Wilayah Kerja Puskesmas Martapura II
}

\author{
Insana Maria \\ ${ }^{1}$ Dosen STIKES Intan Martapura, Kalimantan Selatan \\ Email: maria.insana82@gmail.com
}

\begin{abstract}
Pulmonary Tuberculosis is a disease that is very rapidly transmitted. The increasing number of pulmonary tuberculosis sufferers in Indonesia is caused by unhealthy behavior. The behavior of pulmonary tuberculosis patients in preventing transmission is also in poor category. Pulmonary tuberculosis prevention program is related to the problem of knowledge and behavior of the community, family, and patients. This study aims to determine the relationship between family knowledge and pulmonary tuberculosis transmission prevention behavior in the work area of Martapura II Public Health Center. This study was conducted using an analytical method with a correlation research design, sampling technique with total sampling of 30 respondents. Meanwhile, the data analysis technique was the chi-square test. The results of data processing using the Chi-Square statistical test showed that for the relationship between family knowledge and the behavior of prevention of transmission of pulmonary tuberculosis, the $\rho$ value $=0.009$ with $\alpha$ value of $=0.05$. So, Ha is accepted, which means there is a relationship between family knowledge and behavior to prevent pulmonary tuberculosis transmission in the work area of the Martapura II Public Health Center in 2019. Optimizing counseling activities and providing information about pulmonary tuberculosis to patients or their family's needs to be done to reduce the increasing number of pulmonary tuberculosis sufferers.
\end{abstract}

Keywords: Knowledge, Behavior, Pulmonary Tuberculosis, Family

\begin{abstract}
Abstrak
Tuberkulosis Paru (atau TB paru) merupakan penyakit yang sangat cepat ditularkan. Meningkatnya penderita TB paru di Indonesia disebabkan oleh perilaku hidup yang tidak sehat. Perilaku pasien TB paru dalam pencegahan penularan juga masih berada dalam kategori kurang baik. Program penanggulangan penyakit TB Paru berkaitan dengan masalah pengetahuan dan perilaku masyarakat, keluarga, serta penderita tuberkulosis paru dalam menanggulangi masalah infeksi bakteri penyebab TB Paru. Penelitian ini bertujuan untuk mengetahui hubungan antara pengetahuan keluarga dengan perilaku pencegahan penularan TB paru di wilayah kerja Puskesmas Martapura II pada tahun 2019. Penelitian ini dilakukan dengan menggunakan metode analitik dengan desain penelitian korelasi, teknik sampling dengan total sampling terhadap 30 responden. Sedangkan, teknik analisis data menggunakan uji chi-square. Hasil pengolahan data yang menggunakan uji statistik Chi-Square didapatkan hasil untuk hubungan antara pengetahuan keluarga dengan perilaku pencegahan penularan TB Paru, diperoleh nilai $\rho=0,009$ dengan nilai $\alpha=0,05 .(\rho<\alpha)$ maka, Ha diterima, yang berarti ada hubungan antara pengetahuan keluarga dengan perilaku pencegahan penularan TB Paru di wilayah kerja Puskesmas Martapura II tahun 2019. Optimalisasi kegiatan penyuluhan dan pemberian informasi tentang penyakit TB Paru kepada penderita ataupun keluarga perlu digiatan untuk dapat menekan bertambahkanya jumlah penderita TB Paru baru.
\end{abstract}

Kata Kunci : Pengetahuan, Perilaku, TB Paru, Tuberculosis paru, Keluarga

\section{Pendahuluan}

Tuberkulosis (TB) paru merupakan penyakit infeksi saluran nafas bagian bawah yang menyerang jaringan paru atau parenkim paru oleh basil Mycobacterium tuberculosis. Tuberkulosis menyebar melalui udara ketika seseorang dengan infeksi TB aktif batuk, bersin, atau menyebarkan butiran ludah mereka melalui udara (Astuti, S. 2013). TB paru merupakan penyakit yang sangat cepat ditularkan. Salah satu penularan TB paru adalah melalui percikan dahak (droplet nuclei) pada saat pasien batuk atau bersin terutama pada orang terdekat pasien, yaitu keluarga yang tinggal serumah dengan pasien (Dina Noviati Kurniasih, 2013).

Pengetahuan keluarga dan masyarakat tentang TB paru yang kurang baik memiliki dampak risiko lebih besar terjadi peningkatan kasus TB paru sedangkan keluarga dan masyarakat yang memiliki pengetahuan yang baik tentang TB paru dapat menurunkan kejadian kasus TB paru. Pendidikan kesehatan mengenai TB paru dapat berupa pengetahuan dan perilaku pasien, keluarga dan masyarakat terhadap pencegahan penularan penyakit TB paru. Pengetahuan dan perilaku yang kurang mengenai penyakit TB paru akan 
menjadikan pasien berpotensi sebagai sumber penularan yang berbahaya bagi lingkungan. Oleh karena itu sangat penting suatu keluarga dengan TB paru untuk memiliki pengetahuan dalam perilaku pencegahan sehingga tidak menularkannya kepada orang lain (Rizki Febriansyah, 2017).

Hasil wawancara awal yang telah dilakukan terhadap 10 anggota keluarga diwilayah kerja puskesmas martapura 2, diperoleh suatu data bahwa tidak semua keluarga mengetahui tentang penyakit TB paru. Sepuluh keluarga yang di wawancarai menunjukkan hasil sebanyak 4 keluarga yang masih kurang mengenal penyakit TB paru seperti pengertian TB paru, tanda gejala, cara penularan, dan cara pencegahan TB paru, 3 keluarga yang hanya mengetahui tanda gejala dan cara penularan TB paru tetapi tidak mengetahui pengertian dan cara pencegahan TB paru, sedangkan 3 keluarga sudah mengenal dan mengetahui tentang pengertian TB paru, tanda gejala, dan cara pencegahan TB paru melalui informasi dari tenaga kesehatan di Puskesmas Martapura II.

\section{Metode Penelitian}

Penelitian ini bersifat deskriptif analitik dengan pendekatan cross-sectional dengan jenis penelitian korelasional, karena bertujuan mengungkapkan hubungan antar variabel pengetahuan keluarga dengan vaiabel perilaku pencegahan penularan TB Paru. Tempat penelitian dilakukan di dilakukan diwilayah kerja Puskesmas Martapura, pada bulan Oktober sampai dengan bulan Februari 2019. Populasi dalam penelitian ini adalah anggota keluarga penderita TB paru di wilayah Puskesmas Martapura 2 dari bulan September sampai Februari yaitu sebanyak 30 orang. Teknik sampling yang digunakan dalam penelitian ini adalah total sampling dengan jumlah 30 sampel. Independent variable pengetahuan keluarga dan Dependent variable perilaku pencegahan penularan TB paru. Instrumen penelitian yang digunakan dalam penelitian ini menggunakan kuesioner yang menghubungkan pengetahuan keluarga dengan perilaku pencegahan penularan TB Paru., Prinsip-prinsip dalam etika penelitian ini, yaitu : Informed Consent (lembar persetujuan), anonymity (tanpa nama), confidentiality (kerahasiaan). Data yang telah dikumpulkan selanjutnya dilakukan pengolahan melalui tahap : editing, coding, scoring. Analisa data dalam penelitian ini dilakukan melalui dua tahap, yaitu analisis univariat dengan pengumpulan data berupa tabel distribusi frekuensi dan Analisis bivariat pada penelitian ini adalah untuk menghubungkan pengetahuan keluarga dengan perilaku pencegahan penularan TB paru. Tekhnik analisa yang digunakan adalah analisa uji statistik dengan uji chisquare dengan derajat kemaknaan $a=0,05$

\section{Hasil Penelitian}

a. Karakteristik Responden

Penelitian ini dilakukan pada responden yang memiliki karakter seperti pada tabel 1.1 di bawah ini:

Tabel 1.1. Karakteristik responden di wilayah kerja Puskesmas Martapura II

\begin{tabular}{ccccc}
\hline No & Karakteristik & & $\mathbf{F}$ & $\mathbf{\%}$ \\
\hline $\mathbf{1}$ & Umur & $<20$ Tahun & 2 & 6,7 \\
\hline & $\mathbf{2 0}-\mathbf{4 0}$ Tahun & $\mathbf{1 4}$ & $\mathbf{4 6 , 7}$ \\
\hline & $41-60$ Tahun & 13 & 43,3 \\
\hline & $>60$ Tahun & 1 & 3,3 \\
\hline $\mathbf{2}$ & Jenis Kelamin & Jumlah & $\mathbf{3 0}$ & $\mathbf{1 0 0}$ \\
\hline & & Perempuan & 13 & 43,3 \\
\hline & & $\mathbf{1 7}$ & $\mathbf{5 6 , 7}$ \\
\hline $\mathbf{3}$ & Jumlah & $\mathbf{3 0}$ & $\mathbf{1 0 0}$ \\
\hline & Pendidikan & SD / Sederajat & 1 & 3,3 \\
\hline & SMP / Sederajat & 6 & 20,0 \\
\hline & SMA / Sederajat & $\mathbf{2 0}$ & $\mathbf{6 6 , 7}$ \\
\hline & Perguruan Tinggi & 3 & 10,0 \\
\hline $\mathbf{4}$ & Jumlah & $\mathbf{3 0}$ & $\mathbf{1 0 0}$ \\
\hline & Buruh & 2 & 6,7 \\
\hline & Pekerjaan & Petani & 3 & 10,0 \\
\hline & Pedagang & 7 & 23,3 \\
\hline & PNS & 1 & 3,3 \\
\hline & Swasta & 6 & 20,0 \\
\hline & & Tidak Bekerja & $\mathbf{1 1}$ & $\mathbf{3 6 , 7}$ \\
\hline & Jumlah & $\mathbf{3 0}$ & $\mathbf{1 0 0}$ \\
\hline & & &
\end{tabular}


Tabel 1.1 menunjukkan bahwa mayoritas responden berusia pada kisaran 20-40 tahun (46.7\%), berjenis kelamin perempuan 17 (56.7\%), berpendidikan SMA/sederajat 20 (66.7\%) dan tidak memiliki pekerjaan 11 (36.7\%).

b. Analisis Univariate

Hasil analisis untuk variable-variabel dalam penelitian ini digambarkan dalam tabel 1.2 di bawah ini.

Tabel 1.2 Distribusi Frekuansi Responden berdasarkan pengetahuan, perilaku pencegahan penularan Tuberculosis Paru di Puskesmas Martapura II Tahun 2019.

\begin{tabular}{|c|c|c|c|c|}
\hline No & Variabel & & Jumlah & $\%$ \\
\hline \multirow[t]{3}{*}{1} & Pengetahuan & Baik & 26 & 86,7 \\
\hline & & Cukup & 4 & 13,3 \\
\hline & & Jumlah & 30 & 100 \\
\hline \multirow[t]{3}{*}{2} & Perilaku Pencegahan & Positif & 25 & 83,3 \\
\hline & & Negatif & 5 & 16,7 \\
\hline & & Jumlah & 30 & 100 \\
\hline
\end{tabular}

Tabel 1.2 di atas menunjukkan bahwa responden memiliki pengetahuan yang baik tentang tuberculosis paru $(26 ; 86 \%)$ dan memiliki perilaku yang positif terhadap pencegahan penularan tuberculosis paru $(25 ; 83.3 \%)$.

\section{c. Analisis Bivariat}

Hasil analisis bivariat variable pengetahuan keluarga dan perilaku keluarga dijelaskan dalam tabel 1.3 di bawah ini.

Tabel 1.3 Tabulasi Silang Pengetahuan Keluarga dengan Perilaku Pencegahan Penularan Tuberculosis Paru di Puskesmas Martapura II Tahun 2019

\begin{tabular}{|c|c|c|c|c|c|c|c|c|}
\hline \multirow[t]{3}{*}{ No } & \multirow{3}{*}{$\begin{array}{l}\text { Pengetahuan } \\
\text { Keluarga }\end{array}$} & \multicolumn{4}{|c|}{ Perilaku } & \multicolumn{2}{|c|}{ Total } & \multirow[t]{3}{*}{ Nilai } \\
\hline & & \multicolumn{2}{|c|}{ Positif } & \multicolumn{2}{|c|}{ Negatif } & & & \\
\hline & & f & $\%$ & $\mathbf{f}$ & $\%$ & f & $\%$ & \\
\hline 1 & Baik & 24 & 80,0 & 2 & 6,7 & 26 & 86,7 & $\rho=0,009$ \\
\hline 2 & Sedang & 1 & 3,3 & 3 & 10,0 & 4 & 13,3 & \\
\hline 3 & Jumlah & 25 & 83,3 & 5 & 16,7 & 30 & 100 & \\
\hline
\end{tabular}

\section{Pembahasan}

Penelitian ini menunjukkan bawah anggota keluarga yang memiliki pengetahuan baik tentang pencegahan penularan TB Paru sebanyak $86,7 \%$ dan keluarga yang memiliki pengetahuan cukup sebanyak $13,3 \%$. Pengetahuan dengan kriteria baik diperoleh sebagian besar responden dapat dipengaruhi oleh informasi yang diterima, baik secara formal maupun informal, juga dapat dipengaruhi oleh pendidikan dan usia responden (Martini, 2019). Pengetahuan responden tentang pencegahan penularan TB Paru termasuk dalam kategori baik salah satunya dipengaruhi oleh faktor umur responden memiliki pengetahuan baik berusia 20 - 40 tahun yakni sebanyak $40 \%$, menunjukan bahwa usia responden masuk kedalam usia produktif. Dimana kelompok usia produktif memiliki daya tangkap yang cepat dan daya ingat yang masih baik dibandingkan usia lanjut sehingga mudah untuk mencari dan menerima informasi yang diberikan tentang penyakit (Rusdiana, 2019).

Hasil penelitian bahwa $46,7 \%$ pada umumnya memiliki pengetahuan baik terdapat pada jenis kelamin perempuan. Laki - laki dan perempuan tidak terdapat perbedaan dalam intelegensia (Insana Maria, 2019). Hasil penelitian menunjukan responden memiliki pengetahuan baik mayoritas memiliki pekerjaan tidak bekerja sebanyak 30,0\%. Hal ini dapat menunjukan bahwa reponden yang tidak bekerja mempunyai waktu luang yang lebih banyak dalam mencari informasi tentang pencegahan penularan TB Paru, dimana informasi 
dapat didapatkan responden dari sarana pelayanan kesehatan pada saat ingin mengambil obat TB Paru anggota keluarganya, menghadiri pertemuan PMO yang menjadi program rutin dari pihak pelayanan kesehatan.

Perilaku Keluarga dalam Pencegahan Penularan TB Paru Di Wilayah Kerja Puskesmas Martapura II menunjukan bahwa $83,3 \%$ memiliki perilaku positif dan $16,7 \%$ memiliki perilaku negatif dalam pencegahan penularan penyakit TB Paru. Persepsi keluarga terhadap penyakit TB Paru dianggap sangat penting untuk segera disembuhkan dan dicegah penularannya yang dimana dalam satu keluarga terdapat penderita TB Paru sehingga munculah motivasi keluarga dalam berperilaku mencegah penularan TB Paru pada anggota keluarga lainnya (Refica Dewita, 2017).

Hasil pengujian statistik dengan menggunakan program komputer degan uji statistik Chi-Square didapatkan nilai $\rho=0,009$ nilai ini lebih kecil dari nilai alpha $(\alpha)=0,05$ maka dengan demikian dapat disimpulkan bahwa hipotesa penelitian (H0 ditolak), yang berarti ada hubungan antara pengetahuan keluarga dengan perilaku pencegahan penularan TB Paru di wilayah kerja Puskesmas Martapura 2 tahun 2019. Hasil penelitian ini menunjukan semakin seseorang memiliki pengetahuan baik maka perilaku pencegahan TB Paru semakin baik pula.

Pengetahuan keluarga tentang pencegahan TB Paru umumnya diperoleh dari hasil penyuluhan yang diberikan oleh perawat saat berada di ruang pojok TB Paru kepada PMO atau keluarga. Semakin banyak informasi yang dimiliki keluarga, maka semakin tinggi pula pengetahuan yang dimiliki dan secara tidak langsung dapat memepengaruhi perilaku keluarga dalam pencegahan penularan TB Paru. Lingkungan, fasilitas dan sarana yang tersedia di Puskesmas Martapura II seperti teradapatnya buku bacaan tentang TB Paru, poster cara batuk, dan cuci tangan yang benar juga dapat mempengaruhi perilaku keluarga dalam melakukan pencegahan penularan TB Paru (Mansyur, S, 2011).

\section{Kesimpulan}

Hasil penelitian tentang hubungan pengetahuan keluarga dengan perilaku pencegahan penularan TB Paru di wilayah kerja Puskesmas Martapura II tahun 2019 menunjukkan pengetahuan keluarga terhadap pencegahan penularan TB Paru dengan kriteria baik sebanyak 86,7\%. Perilaku keluarga dalam pencegahan penderita TB Paru dengan kategori perilaku positif sebanyak $83,3 \%$. Ada hubungan yang signifikan antara pengetahuan keluarga dengan perilaku pencegahan penularan TB Paru di wilayah kerja Puskesmas Martapura II tahun 2019.

\section{Acknowledgment}

Terimakasih yang sebesarnya kami berikan kepada seluruh perawat dan dokter di Wilayah Kerja
Puskesmas Martapura II karena telah di berikan kesempatan untuk melaksanakan penelitian pada pasien dan keluarga yang menderita TBC, selanjutnya terimakasih yang sebarnya bagi pimpinan STIKES Intan Martapura untuk dana penelitian yang telah di berikan.

\section{Daftar Pustaka}

Astuti, S (2013). Hubungan Tingkat Pengetahuan dan Masyarakat Terhadap Upaya Pencegahan Penyakit Tuberculosis di RW 04 Kelurahan Lagoa Jakarta Utara Tahun 2013. Skripsi. UIN Syarif Hidayatullak. Jakarta Batticaca, Fransisca B. 2012.

Dina Noviati Kurniasih. 2013. Hubungan Antara Pengetahuan Dengan Perilaku Pencegahan Penularan Pada Penderita TB Paru di Poli RS Prof. Dr. Sulianto Saroso. Jakarta : Rumah Sakit Prof. Dr. Sulianto Suroso.

Dinata CA, Safrita Y, Sastri S. 2013. Gambaran Faktor Risiko dan Tipe Stroke pada Pasien Rawat Inap di Bagian Penyakit Dalam RSUD Kabupaten Solok Selatan Periode 1 Januari 2010 - 31 Juni 2012. Jurnal Kesehatan Andalas. 2013;2(2). p. 57-61.

Dourman, 2013. Waspada Stroke usia Muda. Jakarta : Cerdas Sehat.

Ignatius dkk, 2017. Perbedaan jenis Kelamin sebagai faktor resiko terhadap keluaran klinis pasien stroke iskemik. Jurnal Kedokteran Diponegoro 6 (2) April 2017.

Insana Maria, dkk. 2019. Perilaku Caring dan Comfort Perawat dalam Kegawatdaruratan. Deepublish. Yogyakarta.

Insana Maria. 2019. Diabetes Self Management Education (Dsme) Dengan Ketidakstabilan Kadar Glukosa Darah Pada Penderita Diabetes Melitus. Duni Keperawatan Jurnal keperawatan dan Kesehatan. Vol. 7 No.1. 1-9.

Iis Pusparina. 2019. Efektifitas Penggunaan Media Leaflet Terhadap Peningkatan Pengetahuan Tentang Narkoba Di Smpn 5 Banjarbaru. Jurnal Kesehatan Suaka Insan 4 (2) 2019.

Mansyur, S. 2011. The Pattern of Antituberculosis Drugs in Pulmonary Tuberculosis Patients, Tuberculosis Outpatient Clinic Persahabatan Hospital. Jakarta : Jurnal Respirologi Indonesia.

Martini. 2019. Hubungan Tingkat Pengetahuan Dengan Kepatuhan Diet Hipertensi Di Puskesmas Astambul. Jurnal Kesehatan Suaka Insan 4 (2) 2019. 
Nursalam, 2017. Metodologi Penelitian Ilmu Keperawatan. Jakarta : Salemba Medika.

Refica Dewita. 2017. Jurnal Gambaran Pengetahuan dan Sikap Pasien TB Paru terhadap Upaya Pengendalian TB Paru. Fakultas Kedokteran Universitas Riau

Rusdiana. 2019. Hubungan Kualitas Tidur Dengan Peningkatan Tekanan Darah Pada Pasien Hipertensi Di Wilayah Kerja Puskesmas Guntung Payung. Jurnal Kesehatan Suaka Insan 4 (2) 2019. 